\title{
Pitfalls in the use of artificial substrates for the diagnosis of Gaucher's disease
}

\author{
YOAV BEN-YOSEPH AND HENRY L. NADLER \\ From the Department of Pediatrics, Northwestern University Medical School, Division of Genetics, \\ Children's Memorial Hospital, Chicago, Ill, USA
}

SUMMARY A patient with Gaucher's disease is described, in whom the disease could not be diagnosed enzymically in liver and leucocytes using artificial substrate 4-methylumbelliferyl $\beta$-glucoside. Normal activity was found in the liver, and about $60 \%$ of control activity was determined in the patient's leucocytes. In contrast, when $\left[{ }^{14} \mathrm{C}\right]-N$-stearoyl glucocerebroside was employed as a substrate, activity as low as $5 \%$ of control has been found in all the proband's tissues, and carrier levels were determined in the proband's parents and maternal uncle.

Gaucher's disease is an autosomal recessive disorder of glucolipid metabolism characterised clinically by hepatosplenomegaly, anaemia, and thrombocytopenia (Brady, 1978). It is probably the most commonly recognised disorder of sphingolipid metabolism. Accumulation of glucosylceramide (glucocerebroside) is found in reticuloendothelial cells of these patients, particularly in cells of the spleen, bone marrow, and liver (Brady, 1978). The primary defect is reported to be a deficiency of the enzyme glucosylceramide $\beta$-glucosidase (EC 3.2.1.45) (glucocerebrosidase) (Brady et al., 1965). Using glucosylceramide as a substrate, a marked decrease of $\beta$-glucosidase activity has been shown in spleen (Brady et al., 1965), liver (Patrick, 1965), skin fibroblasts (Beutler et al., 1971), and leucocytes (Kampine et al., 1967) of patients with Gaucher's disease. Deficiency of $\beta$ glucosidase activity (EC 3.2.1.21) towards synthetic substrates such as 4 -methylumbelliferyl $\beta$-glucoside and $p$-nitrophenyl $\beta$-glucoside has also been reported in patients with Gaucher's disease (Patrick, 1965; Kampine et al., 1967; Beutler and Kuhl, 1970). Of interest, several cases of Gaucher's disease have been reported in which patients could not be distinguished from controls when liver homogenates were assayed with an artificial substrate (Patrick, 1965; Broadhead and Butterworth, 1977; Owada et al., 1977). In addition, total leucocyte artificial $\beta$-glucosidase activity may also be normal in some patients with Gaucher's disease although diminished activity towards the natural substrate is clearly evident (Brady, 1978).

Received for publication 17 April 1978
In the present report a case of Gaucher's disease is described in which 4-methylumbelliferyl $\beta$ glucosidase activity in leucocytes and liver was normal, while deficient glucocerebroside activity using $\left[{ }^{14} \mathrm{C}\right]-N$-stearoyl glucocerebroside was documented. The purpose of this report is to call to the attention of clinicians and pathologists the potential unreliability of artificial substrates to establish the diagnosis of Gaucher's disease. This is especially important because of the ready availability of methylumbelliferyl substrates and the widespread utilisation of these relatively simple assays in clinical laboratories.

\section{Case report}

The patient was referred to Children's Memorial Hospital at $8 \frac{1}{2}$ months of age because of developmental regression, hepatosplenomegaly, hypertonia, and frequent pulmonary infections. The patient was born to a gravida 2, para 1, abortion 1, 27-year-old woman of German-Irish descent. Her husband is of English-Polish ancestry. The pregnancy was uncomplicated, as was the neonatal course. At approximately 2-3 months of age developmental delay was apparent.

Physical examination on admission revealed a child with obvious opisthotonic posturing, inspiratory stridor and nasal congestion, and marked wasting. Significant findings included hepatosplenomegaly, hypertonia, and a high-pitched cry. No cherry red spot was seen. Routine laboratory studies included $9.7 \mathrm{~g}$ haemoglobin, white count $3.4 \times 10^{9} / 1$, and platelet count 6500 . Total serum acid phospha- 
tase was significantly elevated. Bone marrow examination revealed the presence of numerous histiocytes consistent with the diagnosis of Gaucher's disease. A diagnosis of infantile or neuropathic type of Gaucher's disease was made. Liver biopsy showed the presence of multiple clumps of large cells scattered throughout the liver parenchyma. Individual cells showed an eosinophilic cytoplasm with a small, single, central hyperchromatic nucleus. High magnification of the cells revealed coarse and irregularly striated cells, which stained positive with periodic acid Schiff. The liver biopsy was consistent with the diagnosis of Gaucher's disease. The results of the enzyme assays using artificial substrate, as seen in Table 1, were within normal limits.

Table 1 -glucosidase activity towards 4-methylumbelliferyl $\beta$-glucoside in various tissues of the family members

\begin{tabular}{lllc}
\hline Subject & \multicolumn{3}{l}{$\begin{array}{l}\text { 4-methylumbelliferyl } \beta \text {-glucosidase activity } \\
(\text { nmol/h/mg protein })\end{array}$} \\
\cline { 2 - 4 } & Leucocytes & Liver & Fibroblasts \\
\hline Proband & 1.04 & 38.6 & 0.9 \\
Proband's mother & 0.90 & - & 55.2 \\
Proband's father & 0.81 & - & 8.8 \\
Control (average) & 1.73 & 35.4 & 19.6 \\
SD & 0.31 & 4.3 & 2.9 \\
\hline
\end{tabular}

\section{Methods}

Liver was obtained from controls and from the patient by an open biopsy. The 'control specimens' were obtained from two patients undergoing staging laparotomy. Postmortem specimens were obtained from three patients who died with multiple congenital malformation syndromes. Normal liver architecture was found in all control specimens. Leucocytes, cultured skin fibroblasts (Ben-Yoseph et al., 1977), and liver samples were homogenised $(10 \% \mathrm{w} / \mathrm{v})$ in 10 $\mathrm{mmol} / \mathrm{l}$ sodium taurocholate. Whole homogenates were assayed for 4-methylumbelliferyl $\beta$-glucosidase activity at pH 4.3 (Shapira et al., 1976) and glucocerebrosidase activity at pH $5 \cdot 9$. Glucocerebroside was radiolabelled according to Erickson and Radin (1973) by alkaline hydrolysis of $N$-stearoyl-DLdihydrosphingosine and acylation of the glucosylsphingosine with $\left[1-{ }^{14} \mathrm{C}\right]$ stearic acid. Glucocerebrosidase activity was measured at $37^{\circ} \mathrm{C}$ by adding 100 $\mu \mathrm{l}$ of tissue preparation (10-50 $\mu \mathrm{g}$ protein) to $100 \mu \mathrm{l}$ sonicated mixture of $30 \mathrm{nmoles}\left[{ }^{14} \mathrm{C}\right]-\mathrm{N}$-stearoyl glucocerebroside ( $600 \mathrm{cpm} / \mathrm{nmol}), 250 \mu \mathrm{g}$ Cutscum, and $250 \mu \mathrm{g}$ sodium taurocholate in $0.1 \mathrm{M}$ potassium phosphate buffer pH 5.9. After 30 min incubation, $1 \mathrm{ml}$ chloroform/methanol 2/1 was added, and the product ${ }^{14} \mathrm{C}$ ceramide was recovered in the lower layer and separated from the unreacted substrate by thin-layer chromatography on silica gel $\mathrm{G}$ in chloro- 므 form/methanol/water $110 / 40 / 6\left(R_{\mathrm{f}}=0.76\right)$. The product was extracted by the same solvent mixture, and radioactivity was measured in a liquid scintilation spectrometer.

\section{Results}

$\beta$-glucosidase activities assayed with artificial and natural substrates in leucocytes, liver, and fibroblasts of the patient, and in leucocytes and fibroblasts of her parents, are presented in Tables 1 and 2 . Using radiolabelled glucocerebroside as a substrate, activity as low as $5 \%$ of control has been found in all $\dot{\omega}$ the proband's tissues, and heterozygote levels in

Table 2 B-glucosidase activity towards

$\left[{ }^{14} \mathrm{C}\right]-\mathrm{N}$-stearoyl-glucocerebroside in various tissues of the family members

\begin{tabular}{llll}
\hline Subject & \multicolumn{4}{l}{$\begin{array}{l}\text { Glucocerebrosidase activity } \\
\text { (nmol/h/mg protein) }\end{array}$} \\
\cline { 2 - 4 } & Leucocytes & Liver & Fibroblasts \\
\hline Proband & 0.39 & 2.5 & 10.0 \\
Proband's mother & 2.75 & - & 87.5 \\
Proband's father & 2.33 & - & 68.4 \\
Control (average) & 5.83 & $65 \cdot 1$ & 191 \\
SD & 0.72 & 9.0 & 22 \\
\hline
\end{tabular}

tissues of the proband's parents. This deficiency could not, however, be demonstrated in the patient's liver and leucocytes when assayed with 4-methyl- $\mathbb{\mathbb { Q }}$ umbelliferyl $\beta$-glucoside as a substrate. Normal $\overrightarrow{\vec{O}}$ activity was found in the liver, and about $60 \%$ of $\frac{0}{3}$ control activity was detemined in the patient's leucocytes. The patient's fibroblasts demonstrated the deficiency with the artificial substrate. Of interest, more than twice the control activity was found in fibroblasts of the patient's mother. Another member of this family, the proband's maternal uncle, was found to be a carrier for Gaucher's disease when assayed with the natural substrate in both leucocytes and fibroblasts $(41.5 \%$ and $38.3 \%$. of control respectively), but, using the artificial substrate, heterozygote level has been shown only in the fibroblasts $(48.5 \%$ of control), whereas in the leucocytes normal activity was found.

\section{Discussion}

The diagnosis of Gaucher's disease can be made

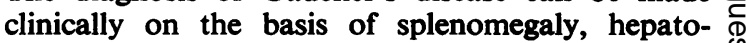
megaly, and the presence of Gaucher cells in bone $\stackrel{\circ}{+}$ marrow aspirates. In order to establish the diagnosis, $T$ one should provide an evidence for either gluco- 
cerebroside accumulation in liver biopsy and, more important, deficiency of glucocerebrosidase activity in the patient's tissues. This is especially true because of the importance for identification of heterozygotes and the capability of intrauterine detection. Although an assay with an artificial substrate has the advantage of simplicity, it is not reliable in some cases of Gaucher's disease, especially when liver is the source of diagnostic material (Patrick, 1965; Broadhead and Butterworth, 1977; Owada et al., 1977). This is probably due to $\beta$-glucosidase activity of a distinct enzyme, neutral $\beta$-galactosidase, which possesses activity towards both aryl- $\beta$-galactosides and aryl$\beta$-glucosides at $\mathrm{pH} 5-6$. The concentration of neutral $\beta$-galactosidase in liver, although variable, is relatively high compared to fibroblasts, and that may explain why fibroblasts are more reliable when artificial substrate is used.

The most important consequence of these observations is the need for caution in situations in which enzymic activity would serve as the sole criterion for Gaucher's disease. The diagnosis of Gaucher's disease cannot be ruled out on the basis of normal $\beta$-glucosidase activity towards an artificial substrate, and in such cases the activity assay should employ the natural substrate, glucocerebroside.

\section{References}

Ben-Yoseph, Y., Burton, B. K., and Nadler, H. L. (1977). Quantitation of the enzymically deficient cross reacting material in $\mathbf{G M}_{1}$ gangliosidoses. American Journal of Human Genetics, 29, 575-580.

Beutler, E., and Kuhl, W. (1970). The diagnosis of the adult type of Gaucher's disease and its carrier state by demonstration of deficiency of $\beta$-glucosidase activity in peripheral blood leukocytes. Journal of Laboratory and Clinical Medicine, 76, 747-755.
Beutler, E., Kuhl, W., Trinidad, F., Teplitz, R., and Nadler, H. (1971). $\beta$-glucosidase activity in fibroblasts from homozygotes and heterozygotes for Gaucher's disease. American Journal of Human Genetics, 23, 62-66.

Brady, R. O. (1978). Glucosyl ceramide lipidosis: Gaucher's disease. In The Metabolic Basis of Inherited Disease, edited by J. B. Stanbury, J. B. Wyngaarden, and D. S. Fredrickson, 4th edition, pp. 731-746. McGraw-Hill, New York.

Brady, R. O., Kanfer, J. N., and Shapiro, D. (1965). Metabolism of glucocerebrosides II. Evidence of an enzymatic deficiency in Gaucher's disease. Biochemical and Biophysical Research Communications, 18, 221-225.

Broadhead, D. M., and Butterworth, J. (1977). The diagnosis of Gaucher's disease in liver using 4-methylumbelliferyl- $\beta$-D-glucopyranoside. Clinica Chimica Acta, 75, 155-161.

Erickson, J. S., and Radin, N. S. (1973). N-Hexyl-Oglucosyl sphingosine, an inhibitor of glucosyl ceramide $\beta$-glucosidase. Journal of Lipid Research, 14, 133-137.

Kampine, J. P. Brady, R. O., Kanfer, J. N., Feld, M., and Shapiro, D. (1967). Diagnosis of Gaucher's disease and Niemann-Pick disease with small samples of venous blood. Science, 155, 86-88.

Owada, M., Sakiyama, T., and Kitagawa, T. (1977). Neuropathic Gaucher's disease with normal 4methylumbelliferyl- $\beta$-glucosidase activity in the liver. Pediatric Research, 11, 641-646.

Patrick, A. D. (1965). A deficiency of glucocerebrosidase in Gaucher's disease. Biochemical Journal, 97, 17C-18C.

Shapira, E., David, A., DeGregorio, R., and Nadler, H. L. (1976). Separation of $\beta$-galactosidases and $\beta$ glucosidases from human liver. Enzyme, 21, 332-341.

Requests for reprints to: Dr Y. Ben-Yoseph, Division of Genetics, Children's Memorial Hospital, 2300 Children's Plaza, Chicago, Illinois, 60614. 